\title{
Identifying Where the Values Come from IT-Innovations in Health and Social Care
}

\author{
Vivian Vimarlund ${ }^{1,2}$, Sabine Koch $^{3}$ \\ ${ }^{1}$ Research Center of Information Technology and Information Systems, Department of Informatics, \\ Jönköping International Business School, Jönköping, Sweden \\ ${ }^{2}$ Linköping University, Linköping, Sweden \\ ${ }^{3}$ Health Informatics Centre, Department of Learning, Informatics, Management and Ethics, \\ Karolinska Institutet, Stockholm, Sweden \\ Email: vivian.vimarlund@jibs.hj.se, sabine.koch@ki.se
}

Received August 4, 2012; revised September 13, 2012; accepted September 27, 2012

\begin{abstract}
Studies aimed to capture the effects of IT-innovations in health and social care have shown that there is a gap between expected and factual outcomes. Many decision makers feel the need to articulate an ideal end-state for their organizations. Striking the balance between novelty and believability of such an ideal end-state is often tricky and they become neither satisfied with the ideal not the visioning. In this study, we explore the contribution of IT-innovations to health and social care. The results showed that coherence between context and IT-innovation is important to capture effects and outcomes. Being coherent rather than visionary contributes to identify where you are, as an organization, and to capture effects and outcomes that "make sense" in the context in question. The paper makes an exposition from the model building, algorithm design to performance analysis and contributes to the academic prosperity in Intelligent Information Management The knowledge generated is expected to provide input when identifying goals that IT-investments are supposed to achieve.
\end{abstract}

Keywords: IT-Innovation; Intelligent Information Management; Health and Social Care; Coherence

\section{Introduction}

Innovation is a fundamental dynamic capability allowing organizations to renew their products and services offerings in order to match or create market changes. Since Schumpeter wrote his book the theory of economic development [1] scholars have emphasized the importance of innovation as driver of structural changes and economic growth.

Investments in IT-innovations in health and social care are usually done to improve productivity and performance in the delivery of services, to enable new ways of interaction within individuals, to achieve organizational flexibility, increasing vertical and horizontal integration, and/or to develop new business models [2].

Leaders and stakeholders at all levels are interested in knowing where the contributions of IT-innovations to health and social care migrate from. Previous research in the area of health informatics, has, however, shown that the introduction of IT-innovations has profound consequences for complex organizations, such as health and social care, and usually brings, i.e. changes in the organizations' structure, changes in work processes, as well as changes in interaction with and within practitioners and patients [2-5]. The results have also shown that there is a need to adapt IT-based innovations (products or services) to organizational context; otherwise large unexpected adverse effects have deep and long-term impact that affects the delivery of care services [6-8] as well as the productivity, effectiveness and efficacy.

While there are many emerging initiatives, that attempt to capture benefits or value of the implementation and use of IT-innovations in health and social care, it is our contention that it will require more studies about which kind of impacts are coherent to expect depending of the organizational context in which the innovation is applied and the type of innovation implemented. Most of the available studies have been limited to the investigation of specific issues, e.g. how IT can support managers to distribute the information throughout the organization [8]; how technological developments have made high quality services more cost-effective; or how technology can be introduced to meet competition [9-11].

The aim of this study is to make an exposition from a model building to performance analysis and explore the contribution of IT-innovations to health and social care organizational contexts. The knowledge generated is expected to provide input when identifying goals that 
IT-investments are supposed to achieve and contributes to the academic prosperity in Intelligent Information Management.

\section{Method}

A review of the literature on health IT evaluation for the years 2000-2011 was performed at the first step of the study in order to identify previous studies related to the effects of IT-innovations in health and social care. The review was performed in an iterative form in collaboration with researchers from the Swedish national e-health network (a network that groups senior researchers in the area of Health Informatics at a national level). In contrast to systematic review, the interactive process allowed us to summarize the findings of the literature and extend the number of reviewed papers and achieve a broad coverage of the field rapidly.

We limited the search to studies related to impacts of IT-innovations in the area of health informatics and published during 2003 and 2010. We searched therefore articles using terms and combination of terms such as: evaluation of IT-innovations, economic evaluations of IT for health and social care, economic investment in IT-based innovations. The searches were conducted using the PubMed, MEDLINE, NLM, and OT seeker.

The bibliographic findings were read in its totality to decide if they belong to the scope of this study or not. Studies considered interesting, $(n=145)$ were those with an explicit focus on how to evaluate and capture benefits of IT-based innovations in health and social care. Studies aimed to evaluate technical issues, pure usability effects or evaluation of e-health services from a socio-technical perspective was not considered.

From the literature, we concluded that mainly three methods are used to perform the studies. They are: surveys, case studies, and test (including clinical testing). Many of the IT-innovations mentioned in the studies we have examined are relatively common, and usually are electronic health record (EHR, EHR and/or CPR), decision support and telemedicine services. EHR constitute $44 \%$ of the number of studies. Decision support systems constitute $34 \%$ of the number of studies. Telemedicine represents $12 \%$ of the studies. Patient portals represent only $10 \%$ of the studies.

Evaluations of IT-based innovations tend in general to be concerned with usefulness and user-related issues such as user acceptance and satisfaction and attitudes towards new systems. We found even some studies that aimed to evaluate the effects of IT-innovations on the quality of work performance. Studies that focus on how to manage information systems report the positive effects of the technology in use and its effects for the quality of care, or improvements in management and work process.

Studies performed with the aim to evaluate the finan- cial impacts of introducing IT-innovations seldom use a systematic identification of all costs. Usually the studies that aim to capture the contribution of IT-innovations to health and/or social care concern user attitudes and perspectives, user satisfaction, and the usefulness of the systems implemented. They normally missed the relationship between usability and economic or usefulness and cost-effectiveness

The most common techniques that the studies have used to capture the economic effects of IT-innovations are current market prices or loss of income. The articles give, however, no clear picture of how the effects have been measured and many times only the direct effects were included in the calculations. The studies are mostly descriptive and indicate the difficulty in measuring qualitative effects of changes. They are usually carried out a priori, i.e. before an IT-innovation has been introduced and used in practice and thus cannot confirm that any anticipated effects have been realized. In some cases, studies have been conducted a-posteriori, noting that the promise of economic gain has not been realized. Empirical attempts to demonstrate or measure the Return on Investment (ROI), has often failed due to the complexity of health and social care organizations, or are of limited use when evaluation is only conducted on prototypes with a limited number of users.

The most common indicators used to express impacts of IT-innovations in the reviewed articles are:

- Increased incomes related to a general use of electronic journals;

- Cost reductions as a consequence of reduced time for paper-based work or for reduction of printing documentation;

- Reduction of costs for medicine due a more effective prescription process;

- Costs reductions due to effectiveness of work-routines;

- Cost reductions for less administrative support;

- Productivity improvements both at the individual and organizational level;

- Quality improvement of care processes and its subsequent reduction of costs due to less;

- Reduction of costs due to errors both in processes, prescriptions and treatment.

A general reflection that we find in the studies reviewed is that concrete evidence of the benefits of ITbased innovations are still few and of varying quality. The articles give no clear picture of how the effects have been measured and normally only the direct effects were included in the calculations. The benefits of IT innovations depend heavily on factors that may take considerable time to reach full power. It often means that the total benefits are rarely identified in the short term. Although much research has been done in this area it is still the case that IT-innovations lead to un-expected costs and 
organizational changes.

Most of the literature indicates, however, the limitations of a strictly quantified economic framework to measure the benefits in relation to investments in ITinnovations in health and social care [7-143]. Most of the studies are descriptive and indicate the difficulty in measuring qualitative effects of changes. A significant trend can be seen in an increased focus on systemic perspective that takes into account several areas such as organization, patient perspective and social consequences. It is interesting to note that most of the studies included in this review, did not discuss a specific theory, approach or model to be applied when evaluating IT-innovations and its contribution to health and social care organizational contexts, and none study generated new theories or extended old ones. Furthermore, many studies perform formative evaluations, and a high proportion of studies perform summative evaluations.

Previous research shown, however, that IT is used for different aims in different organizations, [2,5,10,11,20, $25,34,38,48,49,51,65,95,117,118,121,123,131,144,145]$ consequently, it is rational to expect that in order to capture where the values of IT-innovations come from it is necessary to first identify the context in which IT is implemented. For this reason, when building the contexts' landscape in this study, we used the principle of coherence [11] and tried to reflect these organizational contextual differences by theoretically classifying the contexts in which an IT-innovation is applied into three types:

The Micro context: Characterized by IT investments in systems that supports exchange of information and communication between one patient and its current healthcare provider as well as the production of basic services at the local organization.

The Intra- and inter-organizational context: Characterized by a multiple organizational perspective and includes investments in IT-innovations that support cooperation, communication and work flows as well as the production of services between several different health and social care organizations.

Virtual networks context: Characterized by a patient focused perspective and includes investments in IT-innovations where the healthcare receiver is an active actor and influences the demand and supply of services at both the micro and the inter- and intra-organizational level.

All propositions related to the contexts' landscape were discussed with senior researchers belonging to the Swedish national e-Health research network and representatives from The Swedish Association of Local Authorities and Regions, Center for eHealth (CeHis). In a series of iterative drafts, the effects reflected what was considered of key importance and coherent between a vision and what can be expected from specific IT-inno- vations in each specific context were discussed and analyzed. Researchers and practitioners were asked to use their experience to decide if the effects and outcomes proposed at each specific context were coherent with the expectations stakeholders believe IT-innovations should bring to complex organizations such health and social care organizations. They were also asked to deal with each context separately, in order to be able to set boundaries and see adjacent possibilities in each environment or context.

A first report was distributed [145] for comments to all the individuals that participated in the workshops or seminars. The report was further discussed with national authorities, CeHis, county councils representatives and IT-managers. A final report was produced at the end of 2010 [144] and distributed through the Santa Anna ITResearch Institute at a national level. During 2011 a series of case studies were performed in order to validate the contexts and their respective effects and outcomes. A final report in which both the contexts and the case studies' results are presented was produced and distributed to all participants in the study, at the end of 2011.

Definition: An IT-innovation can be defined as "a mayor technological change resulting in the creation of a substitute technology for a particular organization" products and services or processes. The emergence of digital imaging as opposed to analog ones in healthcare can serve as an illustrative example of an innovation.

\section{Identifying the Contributions of IT-Innovations: From Micro-Level to Virtual Networks}

\subsection{The Micro-Level Context}

Investments in IT-innovations at the micro level are mainly made to reduce costly time-consuming errors from manual data entry, and to increase system usability. Health and social care organizations focus on facilitating internal communication and stimulating a good information management for the local work team. IT-innovations are mainly used to improve administrative issues i.e., to keep records, order supplies, to support the provision of basic services (i.e. prescription renewal or cancellation of appointments) facilitating one way communication between stakeholders (i.e. patients and practitioners) with simple interfaces.

IT-innovations at this level, normally, do not allow possibilities to interact or to exchange information with the patients in real-time. There have neither any automation nor verification mechanisms to confirm the receipt of a request. In some cases e-mail is sent to confirm requests, but they are usually not sent in real-time or automatically.

Main outcomes at this level are related to the possibil- 
ity to share information between different actors at the micro-level, reduce unnecessary consumption of resources, reduce the work-overload of frontline personnel and improve decision making process. Economic benefits that are generated at this level are not directly related with net economic savings for the single organization or for the investor. They are usually short-term returns as a result of reductions in transaction costs when administrative services can be rationalized (Table 1).

\subsection{The Intra- and Inter-Organizational Context}

Health and social care organizations at this level are often developing less hierarchical alternatives for organizing work and changing the way individuals (care professionals and patients) interact with and within organizations.

IT-innovations contribute at this level to create a modern and flexible information exchange along the entire chain of care empowering end-users to actively use IT for communication and interaction patters. New structures created by the use of an IT-innovation improve internal and external integration of actors, supporting and enabling the creation of integrated services (i.e. the possibility to collaborate with pharmacies or social care actors). An important challenge at this level is the fact that the benefits of the implementation and use of technological innovations do not always go to the same stakeholder who funded the IT-initiative.

The relationship between cost and effectiveness is not necessarily directly or linear. Main challenges are, paradoxically, not related to the technology and its functional capacities, but to the willingness and frequency of the use of IT, and to governance. Of crucial importance is to keep decisions about investment in IT-innovations separated from decisions concerning the financing of the innovation, and being coherent to identify the possibilities that the IT-innovation offers to the context to reduce the time and space of the communication and collaboration simultaneously to, to not be vulnerable to changes (Table 2).

\subsection{Virtual Networks' Context}

Health and social care organizations at this level are working actively with the total integration of organizational structures. The paradox of this step is that the benefits derived from IT-innovations become easier to appreciate, although the technology is interwoven in all activities. The values cannot any longer be analyzed at a single level. This is because IT-innovations has become powerful, complex and embedded in the organizations and accompanied by considerable changes in structures, work procedures and sometimes in division of labor.

The patient, at this step, is assumed to be the actor who is best updated on his own needs and preferences and knows best which services he/she wants to demand and adopt an active role becoming an important factor in the production and delivery of services. The ambition is to enable the patient to take an active part in his/her own care and to stimulate him/her to actively participate in the demand of services. Examples of IT applications at this level are: Portals, blogs, networks, social media, and business intelligence solutions support and encourage interaction with external private service providers/suppliers.

Effects emerge, at this level, from an increased patient involvement (awareness and empowerment). This presupposes, however, that patients are well informed about

Table 1. IT-innovations, effects and outcomes at the micro-level context.

\begin{tabular}{|c|c|c|}
\hline \multirow{2}{*}{ IT-innovation } & \multicolumn{2}{|r|}{ The micro level context } \\
\hline & Effects & Outcomes \\
\hline \multirow[t]{2}{*}{$\begin{array}{l}\text { Electronic decision support } \\
\text { systems (EHR, EPR) }\end{array}$} & $\begin{array}{l}\text { Electronic scheduling of appointments } \\
\text { and registration of tasks }\end{array}$ & $\begin{array}{l}\text { - } \\
\text { - } \\
\text { - } \\
\text { Redullocation of time and resources } \\
\text { registration }\end{array}$ \\
\hline & Organizational learning & $\begin{array}{l}\text { - Increase and stimulate information and knowledge exchange } \\
\text { between different care givers at the same unit. } \\
\text { - Support awareness of patient safety }\end{array}$ \\
\hline Virtual logistic systems & $\begin{array}{l}\text { Effective and fast access to information } \\
\text { for joint planning and distribution of } \\
\text { resources }\end{array}$ & $\begin{array}{l}\text { - } \quad \text { Shorter lead time for communication } \\
\text { - } \quad \text { Integration of the activities along the logistics value chain. } \\
\text { - } \quad \text { Shoactive planning of resources } \\
\text { - } \quad \text { Reduce costs transaction costs due to effective and fast access to } \\
\text { information for joint planning }\end{array}$ \\
\hline $\begin{array}{l}\text { E-basic services i.e. booking } \\
\text { systems, birthregistration, } \\
\text { renewal of prescriptions }\end{array}$ & Customization of services & $\begin{array}{l}\text { - Flexibility and new options for booking/outbookning of appointments } \\
\text { - } \quad \text { Reduction of waiting time for accessibility of services (i.e. renewal of } \\
\text { prescriptions, electronic birth registration) }\end{array}$ \\
\hline
\end{tabular}


Table 2. IT-innovations, effects and outcomes at the intra and interorganizational context.

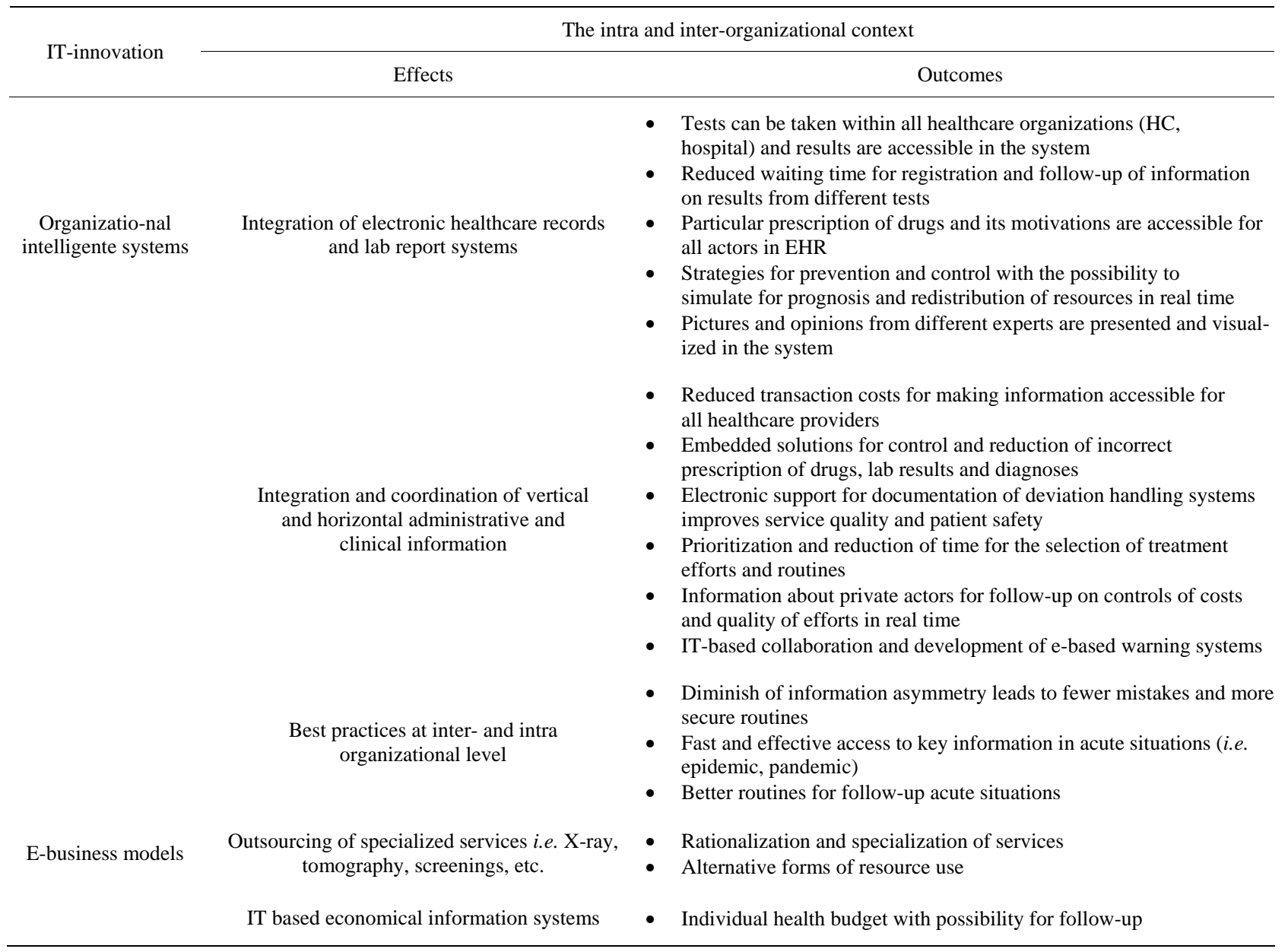

the challengers and requisites that of the use of an available IT-innovation demand, and how or if it should affect them at the individual level. Patients taking the initiative to active use technological innovations are those who trust in IT and those who are willing to test alternative communication tools but even those that are willing to in parallel to take the initiative and invest time and efforts.

Investments in IT-innovations are seldom financially sustainable at the short run in this context. They are a combination of investments in a specific IT-innovation, and investments in changing the relationship between practitioners and patients as well as the manner to produce and up-date health and social care information. Additional costs, not having been present at the previous two levels of the model appear at this level. Namely costs for producing trustfully and state-of-the art information, costs for financing the accessibility to services to the patient, costs for organizing the supply of information in real-time and in a new context and costs for supporting the new and the old system in parallel, at least for a while. There exists at this level, consequently, a clear need for to develop innovative and sustainable business models that meet the economic and administrative requirements as well as the demand for stimulating patient to being active demanders of services (Table 3).

\section{Discussion}

There is today a good deal of wisdom and experience in how to identify the values and contributions of IT-innovations outside of the health informatics area (i.e. ERPsystems). There is no shortage of writers in the IT field who have tackled the problematic task of IT-innovation investment appraisal. When discussing where the values of IT-innovations migrate from in health and social care, issues concerning process reengineering, resource allocation, organizational issues and individual behavior and its consequences are usually discussed often as exogenous factors related to the use of a new IT system. Evaluation reports have, usually, shown that the introduction of IT in health and social care leads to failures, resistance to use ICT or to a non-optimal use of the scarce resources [2,6, 7,16,47,53,100,107,144].

Investments in IT-innovations are usually made based 
Table 3. IT-innovations, effects and outcomes at the virtual networks context.

\begin{tabular}{|c|c|c|}
\hline \multirow{2}{*}{ IT-innovation } & \multicolumn{2}{|r|}{ The virtual networks context } \\
\hline & Effects & Outcomes \\
\hline & Innovative work-routines & $\begin{array}{l}\text { - } \quad \text { Re-design of work routines and processes and electronic access to } \\
\text { individual information } \\
\text { - } \quad \text { Possibilities to control number of visits and reallocate resources } \\
\text { - } \quad \text { Control of consumption of services } \\
\text { - } \quad \text { Automatic reminders or follow-up on care plans or healthcare efforts and } \\
\text { - } \quad \text { Post information or questions before an appointment or follow-up of } \\
\text { information during a care-process }\end{array}$ \\
\hline On-line communities & $\begin{array}{l}\text { "Health-facebook" or such including } \\
\text { tools for simulation and visualization } \\
\text { for preventive efforts }\end{array}$ & $\begin{array}{l}\text { - eHealthcare teams for virtual care and to particularly support for } \\
\text { chronically ill individuals } \\
\text { - The healthcare receiver is offered possibilities to participate in } \\
\text { specialized "communities" with chat rooms and interaction opportunities } \\
\text { - Faster and more effective decision making that favors the healthcare } \\
\text { receiver and makes administration for certain matters more cost-effectives } \\
\text { - Telemedicine and distance healthcare within all areas: elderly, children, } \\
\text { chronically ill, palliative healthcare, cardio vascular etc } \\
\text { - Follow-up in areas and of healthcare receivers with special healthcare } \\
\text { needs, with the possibility for cooperation between external actors }\end{array}$ \\
\hline $\begin{array}{l}\text { Virtual systems for } \\
\text { control and } \\
\text { accounting }\end{array}$ & $\begin{array}{l}\text { Automatic decisions for third party } \\
\text { (i.e. health insurance office or } \\
\text { insurance company) }\end{array}$ & $\begin{array}{l}\text { - Faster and more effective decision making that favors the healthcare } \\
\text { receiver and makes administration for certain matters more cost-effective } \\
\text { - Information/answers for costs/ support of different efforts between and } \\
\text { within different healthcare providers, including both private and public } \\
\text { healthcare providers } \\
\text { - Real-time interaction with external organization such as social security } \\
\text { offices } \\
\text { - Cost-control and effective management of demand of services both at the } \\
\text { individuals and group level }\end{array}$ \\
\hline & $\begin{array}{l}\text { Standardization with the healthcare } \\
\text { receiver in focus }\end{array}$ & $\begin{array}{l}\text { - Standardization of health and social care information about treatments and } \\
\text { interventions, it consequences and costs at a national level } \\
\text { - Standardization of answers related to private life issues offers possibility to } \\
\text { keep anonymity if it is desirable and reduce personal visits to primary } \\
\text { healthcare } \\
\text { - Facilitate search services and comparison of providers for the health care } \\
\text { receiver }\end{array}$ \\
\hline
\end{tabular}

on a vision designed beforehand and in which a series of expectations of improving organizational operations, reducing costs, controlling resource allocation and achieving of a higher standard of quality are described. The generation of evidence on the success of these initiatives cannot be possible without a coherent relationship between the context and the specific the type of innovation analyzed.

Many decision makers feel the need to articulate an ideal end-state for their organizations. Striking the bal- ance between novelty and believability of such an ideal end-state is often tricky and they become neither satisfied with the ideal not the visioning. Being coherent rather than visionary contributes to identify where you are, as an organization, and to capture effects and outcomes that "make sense" for health and social care organizational contexts. Health and social care organizations must find ways to interpret effects of IT-innovations so as to make their environments more predictable in order to understand the co-evolution needs that IT-innovations demand. 
Coherence between a specific context, IT-innovation, effects and outcomes serves as the glue, which allows both managers and the organization to reassert identity in the face of continues change demanded by technology. Roles, processes and interactions evolve continually with each new occasion of use of IT-innovation, because new situations, negotiations, and activities, inevitably recast it in a new form. Change in complex organizations as health and social care cannot longer be undertaken as though ceteris paribus was true. It is necessary to find the coherence between linkages from an IT-innovation at each specific organizational context. While the importance of coherence has not yet become a common issue to analyze where the values migrates from IT-innovations in health and social care, its critical role is well recognized in managerial contexts, and in other fields like psychology.

Coherent organizations thrive in attainment of their purposes. As coherence between IT-innovation and context increase, a much higher level of organizational coherence and alignment is possible. The adjacent possibilities that IT-innovations allow in the current environment become clearer and new organizational and business opportunities evolves, but at the same time demand investments that normally are not considered when developing a general vision to achieve.

Decision makers can benefit from using the contexts and effects suggested in this article as a practical instrument at the moment to plan investments or identify the outcomes that IT-innovations can bring to the organizations to avoid frustration or mismatch between vision and outcomes. The rapid pace of change in health and social care as a consequence of the increasing use of IT-innovations as substitute of manual routines, poses serious starting problems for any large investment. If IT is to emerge as a beneficial corporate tool, the decision to invest needs to be examined as rigorously as with any other large investment. To do this, it is necessary to use tools, as the contexts suggested in this study that visualize if the investment decisions will come true not just to make food forecasts.

The economic motivation of investments in IT-innovations in health and social-care cannot only be justified by its economic benefits to the investors. The economic risks are thus higher than the ones done at the private sector and sometimes have to sacrifice financial return in favor of social return. However, to motivate stakeholders to invest in social ventures, it is necessary to identify where the contributions of IT-innovations to specific organizational contexts migrates from and have a clear picture about the progression of the outcomes at different levels. Identifying the environmental, organizational and its correspondent outcomes can facilitate to attribute a financial value to them and made an evaluation of the balance between economic efficiency, organizational context and potential contributions of the chosen IT-innovation.

\section{Acknowledgements}

This work has been supported by The Swedish Association of Local Authorities and Regions, Center for eHealth (CeHis) in Sweden. We specially thank Lars Jerlvall for invaluable comments to our drafts and manuscripts. We thank also our research colleagues, from the national eHealth network, and in particularly, Linda Askenäs, Ph.D. and Hanna Danielsson, Ph.D., for participating in the interactive meetings when developing the contexts architecture and for searching complementary literature for this study. Thank you also all the representatives from the National eHealth Research Network for participating in the presentations of the different versions of the national reports.

\section{REFERENCES}

[1] J. Schumpeter, "The Theory of Economic Development: An Inquiry into Profits, Capital, Credit, Interest and the Business Cycle,” Harvard University Press, Cambridge, 1912 and 1936.

[2] V. Vimarlund and N. G. Olve, "Using ICT to Transform Elderly Healthcare," Proceedings of the 12th International Symposium on Health Information Management Research, Sheffield, 18-20 July 2007, pp 127-135.

[3] J. Grimson, W. Grimson and W. Hasselbring, "The SI Challenge in Healthcare," Communications of the ACM, Vol. 43, No. 6, 2000, pp. 49-55. doi:10.1145/336460.336474

[4] M. Berg, "Implementing Information Systems in Health Care Organizations: Myths and Challenges," International Journal of Medical Informatics, Vol. 64, No. 2-3, 2001, pp. 143-156. doi:10.1016/S1386-5056(01)00200-3

[5] N. G. Olve and V. Vimarlund, "Locating ICT's Benefits in Elderly Care,” Medical Informatics and the Internet in Medicine, Vol. 30, No. 4, 2005, pp. 297-308. doi:10.1080/14639230500429363

[6] V. Vimarlund, N. G. Olve, I. Scandurra and S. Koch, "Information and Communication Technology (ICT) and Elderly Homecare-The Hudiksvall Case," Health Informatics Journal, Vol. 14, No. 3, 2008, pp. 195-209. doi:10.1177/1081180X08092830

[7] B. Rahimi, V. Vimarlund and T. Timpka, "Health Information System Implementation: A Qualitative MetaAnalysis,” Journal of Medical Systems, Vol. 33, No. 5, 2009, pp. 359-368. doi:10.1007/s10916-008-9198-9

[8] I. Scandurra, M. Hägglund and S. Koch, "Specific Demands for Developing ICT Systems for Shared Home Care: A User Centred Approach,” Journal on Information Technology in Healthcare, Vol. 5, No. 3, 2005, pp. 279285.

[9] A. Andersson, V. Vimarlund and T. Timpka, "Manage- 
ment Demands on Information and Communication Technology in Process Oriented Healthcare Organizations,” International Journal of Management in Medicine, Vol. 16, No. 2-3, 2002, pp. 188-198.

[10] L. Afrin, K. Courtney, G. Demiris, W. Goossen, C. Lovis, C. Lynch, M. Sondhi, S. Speedie and V. Vimarlund, "Patient-Centered Applications and Mobile Health; Use of IT to Promote Disease Management and Wellness,” Journal of the American Medical Informatics Association, Vol. 15, No. 1, 2008, pp. 8-13.

[11] M. Lissack and J. Roos, "Be Coherent not Visionary," Long Range Planning, Vol. 34, No. 1, 2001, pp. 53-70. doi:10.1016/S0024-6301(00)00093-5

[12] V. P. Aggelidis and P. D. Chatzoglou, "Methods for Evaluating Hospital Information Systems: A Literature Review,” EuroMed Journal of Business, Vol. 3, No. 1, 2008, pp. 99-118. doi:10.1108/14502190810873849

[13] H. Alalwany and S. Alshawi, "Evaluation of E-Health Services: User's Perspective Criteria,” Transforming Government: People, Process and Policy, Vol. 2, No. 4, 2008, pp. 243-255.

[14] E. Ammenwerth, S. Graber, G. Herrmann, T. Burkle and J. Konig, "Evaluation of Health Information SystemsProblems and Challenges," International Journal of Medical Informatics, Vol. 71, No. 2-3, 2003, pp. 125-135. doi:10.1016/S1386-5056(03)00131-X

[15] E. Ammenwerth, U. Mansmann, C. Iller and R. Eichstädter, "Factors Affecting and Affected by User Acceptance of Computer-Based Nursing Documentation: Results of a Two-Year Study," Journal of the American Medical Informatics Association, Vol. 10, No. 1, 2003, pp. 69-84. doi:10.1197/jamia.M1118

[16] E. Balka, “Technology, Governance and Patient Safety: Systems Issues in Technology and Patient Safety," International Journal of Medical Informatics, Vol. 76, No. 1, 2007, pp. 35-47. doi:10.1016/j.ijmedinf.2006.05.046

[17] P. A. Bath, "Health Informatics: Current Issues and Challenges,” Journal of Information Science, Vol. 34, No. 4, 2008, pp. 501-518. doi:10.1177/0165551508092267

[18] A. Baum, S. Figar, J. Serverino, D. Assale, B. Schachner, P. Otero, et al., "Assessing the Impact of Change in the Organization of a Technical Support System for a Health Information Systems (HIS)," Studies in Health Technology and Informatics, Vol. 107, No. 2, 2004, pp. 1367-1370.

[19] P. Bonnabry, C. Despont-Gros, D. Grauser, P. Casez, M. Despond, D. Pugin, et al., "A Risk Analysis Method to Evaluate the Impact of a Computerized Provider Order Entry System on Patient Safety,” Journal of the American Medical Information Association, Vol. 15, No. 4, 2008, pp. 453-460. doi:10.1197/jamia.M2677

[20] J. Bourbeau, J.-P. Collet, K. Schwartzman, T. Ducruet, D. Nault and C. Bradley, "Economic Benefits of Self-Management Education in COPD," CHEST, Vol. 130, No. 6, 2006, pp. 1704-1711. doi:10.1378/chest.130.6.1704

[21] J. Brender, "Handbook of Evaluation Methods for Health Informatics,” Academic Press, Waltham, 2005.

[22] A. Brennan, S. E. Chick and R. Davies, "Taxonomy of Model Structures for Economic Evaluation of Health
Technologies,” Health Economics, Vol. 15, No. 12, 2006, pp. 1295-1310. doi:10.1002/hec.1148

[23] L. Buccoliero, S. Calciolari and M. Marsilio, "A Methodological and Operative Framework for the Evaluation of an E-Health Project,” International Journal of Health Planning and Management, Vol. 23, No. 1, 2008, pp. 3- 20. doi:10.1002/hpm.881

[24] R. Busse, U. Nimptsch and T. Mansky, "Measuring, Monitoring, and Managing Quality in Germany’s Hospitals,” Health Affairs, Vol. 28, No. 2, 2009, pp. 294-304. doi:10.1377/hlthaff.28.2.w294

[25] M. J. Buxton, "Economic Evaluation and Decision Making in the UK," PharmacoEconomics, Vol. 24, No. 11, 2006, pp. 1133-1142. doi:10.2165/00019053-200624110-00009

[26] H. Buysse, G. D. Moor, G. V. Maele, E. Baert, G. Thienpont and M. Temmerman, "Cost-Effectiveness of Telemonitoring for High-Risk Pregnant Women,” International Journal of Medical Informatics, Vol. 77, No. 10, 2008, pp. 641-714.

[27] L. M. Canady, "Implementing a Home Telemonitoring Program,” Home Healthcare Nurse, Vol. 26, No. 4, 2008, pp. 231-236. doi:10.1097/01.NHH.0000316701.15010.e1

[28] B. Chaudhry, J. Wang, S. Wu, M. Maglione, W. Mojica, E. Roth, et al., "Systematic Review: Impact of Health Information Technology on Quality, Efficiency, and Costs of Medical Care,” Annals of Internal Medicine, Vol. 144, No. 10, 2006, pp. 742-752.

[29] J. S. Clark, F. S. Mair, C. O’Donnell and J. Liu, “EHealth: Implementation and Evaluation Research in Scotland-A Scoping Exercise," Journal of Telemedicine and Telecare, Vol. 3, No. 14, 2008, pp, 119-121.

[30] D. C. Classen, A. J. Avery and D. W. Bates, "Evaluation and Certification of Computerized Provider Order Entry Systems," Journal of the American Medical Informatics Association, Vol. 14, No. 1, 2007, pp. 48-55. doi:10.1197/jamia.M2248

[31] P. D. Clayton, S. P. Narus, A. Watson, I. Bowes, T. S. Madsen, A. B. Wilcox, G. Orsmond, et al., "Physician Use of Electronic Medical Records: Issues and Successes with Direct Data Entry and Physician Productivity," AMIA Annual Symposium Proceedings, Washington, 2226 October 2005, pp. 141-145.

[32] S. S. Cohen, "Emerging Benefits of Integrated IT Systems," Healthcare Executive, Vol. 20, No. 5, 2005, pp. 14-18.

[33] R. E. Connely, "If You Build It, Don’t Expect Them to Come," Health Management Technology, Vol. 29, No. 8, 2008, pp. 32-33.

[34] J. Corrigan and D. McNeill, "Building Organizational Capacity: A Cornerstone of Health System Reform," Health Affairs, Vol. 28, No. 2, 2009, pp. 205-215. doi:10.1377/hlthaff.28.2.w205

[35] C. M. Cusack and E. G. Poon, "Evaluation Toolkit Version 3,” Agency for Healthcare Research and Quality, Rockville, 2009.

[36] N. F. de Keizer and E. Ammenwerth, "The Quality of Evidence in Health Informatics: How Did the Quality of 
Healthcare IT Evaluation Publications Develop from 1982 to 2005?” International Journal of Medical Informatics, Vol. 77, No. 1, 2008, pp. 41-49. doi:10.1016/j.ijmedinf.2006.11.009

[37] C. C. Diamond and C. Shirky, "Health Information Technology: A Few Years of Magical Thinking?” Health Affairs, Vol. 27, No. 1, 2008, pp, 383-390.

[38] K. B. Eden, R. Messina, H. Li, P. Osterweil, C. R. Henderson and J. M. Guise, "Examining the Value of Electronic Health Records on Labor and Delivery,” American Journal of Obstet Gynecology, Vol. 199, No. 3, 2008, pp. 301-309. doi:10.1016/j.ajog.2008.07.004

[39] A. Dobrev, et al., "Financing eHealth," European Commission, DG INFSO \& Media, 2008.

[40] C. L. Goldzweig, A. Towfigh, M. Maglione and P. G. Shekelle, "Costs and Benefits of Health Information Technology: New Trends from the Literature," Health Affairs, Vol. 28, No. 2, 2009, pp. 282-293. doi:10.1377/hlthaff.28.2.w282

[41] J. C. Hobson, S. Khemani and A. Singh, "Prospective Audit of the Quality of ENT Emergency Clinic Notes before and after Introduction of a Computerized Template," Journal of Laryngology \& Otology, Vol. 119, No. 4, 2005, pp. 264-266. doi:10.1258/0022215054020359

[42] E. W. Huang and D. M. Liou, "Performance Analysis of a Medical Records Exchange Model,” IEEE Transactions on Information Technology in Biomedicine, Vol. 11, No. 2, 2007, pp. 153-160. doi:10.1109/TITB.2006.875681

[43] D. Kaufman, W. D. Roberts, J. Merrill, T. Y. Lai and S. Bakken, "Applying an Evaluation Framework for Health Information System Design, Development, and Implementation,” Nursing Research, Vol. 55, No. 2, 2006, pp. S37-S42. doi:10.1097/00006199-200603001-00007

[44] H. Laerum, T. H. Karlsen and A. Faxvaag, "Effects of Scanning and Eliminating Paper-based Medical Records on Hospital Physicians' Clinical Work Practice,” Journal of the American Medical Informatics Association, Vol. 10, No. 6, 2003, pp. 588-595. doi:10.1197/jamia.M1337

[45] H. Lærum, T. H. Karlsen and A. Faxvaag, "Use of and Attitudes to a Hospital Information System by Medical Secretaries, Nurses and Physicians Deprived of the Paper-Based Medical Record: A Case Report,” BMC Medical Informatics and Decision Making, Vol. 4, No. 1, 2004, p. 18. doi:10.1186/1472-6947-4-18

[46] A. Likourezos, D. B. Chalfin, D. G. Murphy, B. Sommer, K. Darcy and S. J. Davidson, "Physician and Nurse Satisfaction with an Electronic Medical Record system,” The Journal of Emergency Medicine, Vol. 27, No. 4, 2004, pp. 419-424. doi:10.1016/j.jemermed.2004.03.019

[47] A. Lockamy III and D. L. Smith, "Telemedicine: A Process Enabler for Enhanced Healthcare Delivery Systems,” Business Process Management Journal, Vol. 15, No. 1, 2009, pp. 5-19. doi:10.1108/14637150910931433

[48] A. J. McLeod Jr., "Measuring Success in Inter-organizational Information Systems: A Case Study," Communications of AIS, Vol. 22, 2008, pp. 617-634.

[49] N. Menachemi and R. G. Brooks, "Reviewing the Benefits and Costs of Electronic Health Records and Associ- ated Patient Safety Technologies,” Journal of Medical Systems, Vol. 30, No. 3, 2006, pp. 159-168. doi:10.1007/s10916-005-7988-X

[50] T. Mettler and V. Vimarlund, "Understanding Business Intelligence in the Context of Health Care," Health Informatics Journal, Vol. 15, No. 3, 2009, pp. 1-11. doi:10.1177/1460458209337446

[51] J. B. Metzger, E. Welebob, F. Turisco and D. C. Classen, "The Leapfrog Group's CPOE Standard and Evaluation Tool,” Patient Safety and Quality Healthcare, Vol. 78, No. S1, 2008, pp. S69-S76.

[52] M. Mitka, "Advice on Adopting New Health Care IT Systems," Journal of the American Medical Association, Vol. 301, No. 6, 2009, pp. 587-589. doi:10.1001/jama.2009.37

[53] J. R. Moehr, J. Schaafsma, C. Anglin, S. V. Pantazi, N. A. Grimm and S. Anglin, "Success Factors for TelehealthA Case Study," International Journal of Medical Information, Vol. 75, No. 10-11, 2006, pp. 755-763. doi:10.1016/j.ijmedinf.2005.11.001

[54] A. Mukherjee and J. McGinnis, "E-healthcare: An Analysis of Key Themes in Research," International Journal of Pharmaceutical and Healthcare Marketing, Vol. 4, No. 1, 2007, pp. 349-363. doi:10.1108/17506120710840170

[55] K. Mäkelä, I. Virjo, J. Aho, P. Kalliola, A.-M. Koivukoski, H. Kurunmäki, et al., "Electronic Patient Record Systems and the General Practitioner: An Evaluation Study," Journal of Telemedicince and Telecare, Vol. 11, No. 2, 2005, pp. 66-68. doi:10.1258/135763305775124641

[56] J. C. Niland, L. Rouse and D. C. Stahl, "An Informatics Blueprint for Healthcare Quality Information Systems," Journal of the American Medical Information Association, Vol. 13, No. 4, 2006, pp. 402-417. doi:10.1197/jamia.M2050

[57] H. Nørreklit, "The Balanced Scorecard: What Is the Score? A Rhetorical Analysis of the Balanced Scorecard Accounting," Organizations and Society, Vol. 28, No. 6, 2003, pp. 591-619. doi:10.1016/S0361-3682(02)00097-1

[58] C. Oroviogoicoechea, B. Elliott and R. Watson, "Review: Evaluating Information Systems in Nursing," Journal of Clinical Nursing, Vol. 17, No. 5, 2008, pp, 567-575.

[59] P. R. Orszag, "Evidence on the Costs and Benefits of Health Information Technology," Congressional Budget Office, Washington, 2008.

[60] C. Pagliari, "Design and Evaluation in eHealth: Challenges and Implications for an Interdisciplinary Field," Journal of Medical Internet Research, Vol. 9, No. 2, 2007, p. e15. doi:10.2196/jmir.9.2.e15

[61] C. Pagliari, M. Gilmour and F. Sullivan, "Electronic Clinical Communications Implementation (ECCI) in Scotland: A Mixed-Methods Programme Evaluation,” Journal of Evaluation in Clinical Practice, Vol. 10, No. 1, 2004, pp. 11-20. doi:10.1111/j.1365-2753.2004.00475.x

[62] PHII, “Towards Measuring Value: An Evaluation Framework for Public Health Information Systems," Public Health Informatics Institute, Decatur, 2005.

[63] D. Protti, T. Bowden and I. Johansen, “Adoption of In- 
formation Technology in Primary Care Physician Offices in New Zealand and Denmark, Part 3: Medical Record Environment Comparisons," Informatics in Primary Care, Vol. 16, No. 4, 2008, pp. 285-290.

[64] B. Rahimi and V. Vimarlund, "Introduction of an Integrated Electronic Prescribing System: The Pharmacies' Staff Dimension," Proceedings of the 14th International Symposium on Health Information, Kalmar, 14-16 October 2009, pp. 5-15.

[65] B. Rahimi, V. Vimarlund and B Rahimi and V. Vimarlund, "Methods to Evaluate IT-Based Administrative Systems in Healthcare Setting: A Literature Review," Journal of Medical Systems, Vol. 31, No. 5, 2007, pp. 397432. doi:10.1007/s10916-007-9082-z

[66] E. E. J. Raja, R. Mahal and V. B. Masih, “An Exploratory Study to Assess the Computer Knowledge, Attitude and Skill among Nurses in Health care Setting of a Selected Hospital, Ludhiana, Punjab, India,” 2004. http://ojni.org/8_1/raja.htm

[67] P. A. Reynolds, J. Harper, A. M. Jenner and S. Dunne, "Better Informed: An Overview of Health Informatics," British Dental Journal, Vol. 204, No. 5, 2008, pp. 259264. doi:10.1038/bdj.2008.150

[68] S. V. Rojas and M.-P. Gagnon, “A Systematic Review of the Key Indicators for Assessing Telehomecare Cost-Effectiveness,” Telemedicine and e-Health, Vol. 14, No. 9, 2008, pp. 896-904.

[69] J. K. Rotich, T. J. Hannan, F. E. Smith, J. Bii, W. W. Odero, N. Vu, et al., "Installing and Implementing a Computer-based Patient Record System in Sub-Saharan Africa: The Mosoriot Medical Record System,” Journal of the American Medical Informatics Association, Vol. 10, No. 4, 2003, pp. 295-303. doi:10.1197/jamia.M1301

[70] C. M. Ruland and I. H. Ravn, "Usefulness and Effects on Costs and Staff Management of a Nursing Resource Management Information System," Journal of Nursing Management, Vol. 11, No. 3, 2003, pp. 208-215. doi:10.1046/j.1365-2834.2003.00381.x

[71] M. J. Sculpher, K. Claxton, M. Drummond and C. McCabe, "Wither Trial-Based Economic Evaluation for Health Care Decision Making?” Health Economics, Vol. 15, No. 7, 2006, pp. 677-687. doi:10.1002/hec.1093

[72] E. R. Siegel, "Information Rx: Evaluation of a New Informatics Tool for Physicians, Patients, and Libraries," Information Services \& Use, Vol. 26, No. 1, 2006, pp. 110 .

[73] J. Smyth, "Electronic Health Records and Practice Management Solutions: All-in-One versus Best-of-Breed," Managed Care Outlook, Vol. 21, No. 14, 2008, pp. 1-5.

[74] R. Spicer, “Bytes and Bites’-Using Computerized Clinical Records to Improve Patient Safety in General Dental Practice,” Dental Update, Vol. 35, No. 9, 2008, pp. 614661.

[75] D. Stengel, K. Bauwens, M. Walter, T. Köpfer and A. Ekkernkamp, "Comparison of Handheld Computer-Assisted and Conventional Paper Chart Documentation of Medical Records: A Randomized, Controlled Trial,” The Journal of Bone and Joint Surgery, Vol. 86, No. 3, 2004, pp. 553-560.

[76] Y. Teerawattananon, S. Russell and M. Mugford, “A Systematic Review of Economic Evaluation Literature in Thailand: Are the Data Good Enough to Be Used by Policy-Makers?” PharmacoEconomics, Vol. 25, No. 6, 2007, pp. 467-479. doi:10.2165/00019053-200725060-00003

[77] M. M. Thalanany, M. Mugford, C. Hibbert, N. J. Cooper, A. Truesdale, S. Robinson, et al., "Methods of Data Collection and Analysis for the Economic Evaluation Alongside a National, Multi-Centre Trial in the UK: Conventional Ventilation or ECMO for Severe Adult Respiratory Failure (CESAR),” BMC Health Services, Vol. 8, No. 1, 2008, p. 94. doi:10.1186/1472-6963-8-94

[78] A. H. Tjora and G. Scambler, "Square Pegs in Round Holes: Information Systems, Hospitals and the Significance of Contextual Awareness," Social Science \& Medicine, Vol. 68, No. 3, 2009, pp. 519-525. doi:10.1016/j.socscimed.2008.11.005

[79] C. Tompkins, A. R. Higgins and G. A. Ritter, "Measuring Outcomes and Efficiency in Medicare Value-Based Purchasing,” Health Affairs, Vol. 28, No. 2, 2009, pp. 251259. doi:10.1377/hlthaff.28.2.w251

[80] J. Tsai and G. Bond, "A Comparison of Electronic Records to Paper Records in Mental Health Centers," International Journal for Quality in Health Care, Vol. 20, No. 2, 1008, pp. 136-143.

[81] A. Wakefield, "Patient Safety Investigations: The Need for Interprofessional Learning," Learning in Health \& Social Care, Vol. 8, No. 1, 2009, pp. 22-32. doi:10.1111/j.1473-6861.2008.00192.x

[82] S. J. Wang, B. Middleton, L. A. Prosser, C. G. Bardon, C. D. Spurr, P. J. Carchidi, et al., “A Cost-Benefit Analysis of Electronic Medical Records in Primary Care,” American Journal of Medicine, Vol. 114, No. 5, 2003, pp. $397-$ 403. doi:10.1016/S0002-9343(03)00057-3

[83] W. P. Welch, D. Bazarko, K. Ritten, Y. Burgess, R. Harmon and L. G. Sandy, "Electronic Health Records in Four Community Physician Practices: Impact on Quality and Cost of Care,” Journal of the American Medical Information Association, Vol. 14, No. 3, 2007, pp. 320-328. doi:10.1197/jamia.M2125

[84] F. Verhoeven, L. V. Gemert-Pijnen, K. Dijkstra, N. Nijland, E. Seydel and M. Steehouder, "The Contribution of Teleconsultation and Videoconferencing to Diabetes Care: A Systematic Literature Review," Journal of Medical Internet Research, Vol. 9, No. 5, 2007, p. e37. doi:10.2196/jmir.9.5.e37

[85] M. Whyte, "Computerized versus Handwritten Records," Pediatric Nursing, Vol. 17, No. 7, 2005, pp. 15-18.

[86] A. Wilcox, S. S. Jones, D. A. Dorr, W. Cannon, L. Burns, K. Radican, et al., "Use and Impact of a Computer-Generated Patient Summary Worksheet for Primary Care," AMIA Annual Symposium Proceedings, Washington, 2226 October 2005, pp. 824-828.

[87] F. Williams and S. A. Boren, "The Role of the Electronic Medical Record (EMR) in Care Delivery Development in Developing Countries: A Systematic Review," Informatics in Primary Care, Vol. 16, No. 2, 2008, pp. 139-145. 
[88] V. Vimarlund, N. G. Olve, I. Scandurra and S. Koch, "Information and Communication Technology (IT) and Elderly Homecare-The Hudiksvall Case,” Health Informatics Journal, Vol. 14, No. 3, 2008, pp. 195-209. doi:10.1177/1081180X08092830

[89] V. Vimarlund, "Elderly Health, Homecare and Information Technology (IT) Healthcare IT Management,” Journal of the European Association of Healthcare IT Managers, Vol. 3, No. 3, 2008, pp. 22-23.

[90] S. C. Voelpel, M. Leibold and R. A. Eckhoff, "The Tyranny of the Balanced Scorecard in the Innovation Economy,” Journal of Intellectual Capital, Vol. 7, No. 1, 2006, pp. 43-60. doi:10.1108/14691930610639769

[91] K. Yamamoto, S. Matsumoto, H. Tada, K. Yanagihara, S. Teramukai, T. Takemura, et al., "A Data Capture System for Outcomes Studies that Integrates with Electronic Health Records: Development and Potential Uses,” Journal of Medical Systems, Vol. 32, No. 5, 2008, pp. 423427. doi:10.1007/s10916-008-9147-7

[92] M. M. Yusof, J. Kuljis, A. Papazafeiropoulou and L. K. Stergioulas, "An Evaluation Framework for Health Information Systems: Human, Organization and Technology-Fit Factors (HOT-fit)," International Journal of Medical Informatics, Vol. 77, No. 6, 2008, pp, 386-398.

[93] M. M. Yusof, A. Papazafeiropoulou, R. J. Paul and L. K. Stergioulas, "Investigating Evaluation Frameworks for Health Information Systems,” International Journal of Medical Informatics, Vol. 77, No. 6, 2008, pp. 377-385. doi:10.1016/j.ijmedinf.2007.08.004

[94] S. O. Zandieh, "Challenges to EHR Implementation in Electronic- versus Paper-Based Office Practices,” Journal of General Internal Medicine, Vol. 23, No. 6, 2008, pp. 755-761. doi:10.1007/s11606-008-0573-5

[95] W. P. Zhang, K. Yamauchi, S. Mizuno, R. Zhang and D. M. Huang, "Analysis of Cost and Assessment of Computerized Patient Record Systems in Japan Based on Questionnaire Survey,” Informatics for Health and Social Care, Vol. 29, No. 3-4, 2004, pp. 229-238. doi:10.1080/14639230400005990

[96] L. Zurita and C. Nøhr, "Patient Opinion-EHR Assessment from the Users Perspective," Health Technology and Informatics, Vol. 107, No. 2, 2004, pp. 1333-1336.

[97] J. Meredith, "Electronic Patient Record Evaluation in Community Mental Health,” Inform Prim Care, Vol. 17, No. 4, 2009, pp. 209-213.

[98] K. Ando, J. Koyama, Y. Abe, T. Sato, M. Shoda, Y. Soga, M. Nobuyoshi, T. Honda, K. Nakao, K. Terata, K. Kadowaki, A. Maeda, S. Ogawa, T. Manaka, N. Hagiwara and K. Doi, "Feasibility Evaluation of a Remote Monitoring System for Implantable Cardiac Devices in Japan,” International Heart Journal, Vol. 52, No. 1, 2001, pp. 39-43. doi:10.1536/ihj.52.39

[99] P. Breen, K. Murphy, G. Browne, F. Molloy, V. Reid, C. Doherty, N. Delanty, S. Connolly and M. Fitzsimons, "Formative Evaluation of a Telemedicine Model for Delivering Clinical Neurophysiology Services Part II: The Referring Clinician and Patient Perspective," BMC Medical Informatics and Decision Making, Vol. 10, 2010, p. 49. doi:10.1186/1472-6947-10-49
[100] T. S. Bergmo, "Economic Evaluation in TelemedicineStill Room for Improvement," Journal of Telemedicine and Telecare, Vol. 16, No. 5, 2010, pp. 229-231. doi:10.1258/jtt.2010.009008

[101] A. W. Armstrong, C. Sanders, A. D. Farbstein, G. Z. Wu, S. W. Lin, F. T. Liu and T. S. Nesbitt, "Evaluation and Comparison of Store-and-Forward Teledermatology Applications," Telemedicine and e-Health, Vol. 16, No. 4, 2010, pp. 424-438.

[102] F. Wang, “The Role of Cost in Telemedicine Evaluation," Telemedicine and e-Health, Vol. 10, No. 5, 2009, pp. 954-955.

[103] T. S. Bergmo, "Can Economic Evaluation in Telemedicine Be Trusted? A Systematic Review of the Literature," Cost Effectiveness and Resource Allocation, Vol. 24, No. 7, 2009, pp. 7-18.

[104] M. Le Goff-Pronost and C. Sicotte, “The Added Value of thorough Economic Evaluation of Telemedicine Networks," The European Journal of Health Economics, Vol. 11, No. 1, 2009, pp. 45-55. doi:10.1007/s10198-009-0162-5

[105] J. B. Smith, S. R. Lacey, A. R. Williams, S. L. Teasley, A. Olney, C. Hunt, K. S. Cox and C. Kemper, "Developing and Testing a Clinical Information System Evaluation Tool: Prioritizing Modifications Through End-User Input,” Journal of Nursing Administration, Vol. 19, No. 6, 2011, pp. 252-258. doi:10.1097/NNA.0b013e31821c4634

[106] C. Fröjd, C. L. Swenne, C. Rubertsson, L. Gunningberg and B. Wadensten, "Patient Information and Participation still in Need of Improvement: Evaluation of Patients' Perceptions of Quality of Care,” Journal of Nursing Administration, Vol. 19, No. 2, 2001, pp. 226-236.

[107] J. M. Palm, T. Dart, I. Dupuis, L. Leneveut and P. Degoulet, "Clinical Information System Post-Adoption Evaluation at the Georges Pompidou University Hospital," AMIA Annual Symposium Proceedings, Washington, 1317 November 2010, pp. 582-586.

[108] F. Lau, M. Price, K. Keshavjee and Q. Health, "From Benefits Evaluation to Clinical Adoption: Making Sense of Health Information System Success in Canada,” Electronic Health Care, Vol. 9, No. 4, 2011, pp. e11-e17.

[109] J. S. Wu, F. Y. Shih, C. H. Chiu, Y. L. Yeh, J. J. Yan, C. C. King and M. S. Ho, "Evaluation of an Adjustable Epidemiologic Information System,” PLoS One, Vol. 6, No. 1, 2001, p. e14596. doi:10.1371/journal.pone.0014596

[110] E. Ammenwerth, F. Rauchegger, F. Ehlers, B. Hirsch and C. Schaubmayr, "Effect of a Nursing Information System on the Quality of Information Processing in Nursing: An Evaluation Study Using the HIS-Monitor Instrument," International Journal of Medical Informatics, Vol. 80, No. 1, 2011, pp. 25-38. doi:10.1016/j.ijmedinf.2010.10.010

[111] J. Y. Feng, H. Chen and S. M. Zhu, "Development and Clinical Evaluation of an Anesthesia Information management system," National Medical Journal of China, Vol. 90, No. 35, 2010, pp. 2514-2517.

[112] A. Krishnan, B. Nongkynrih, K. Yadav, S. Singh and V. Gupta, "Evaluation of Computerized Health Management Information System for Primary Health Care in Rural In- 
dia,” BMC Health Services Research, Vol. 310, No. 10, 2010, p. 41.

[113] H. Hyppönen, P. Doupi, P. Hämäläinen, J. Komulainen, P. Nykänen and R. Suomi, "Towards a National Health Information System Evaluation,” Studies in Health Technology and Informatics, Vol. 160, 2010, pp. 1216-1220.

[114] C. Oroviogoicoechea and R. A. Watson, "Quantitative Analysis of the Impact of a Computerised Information System on Nurses' Clinical Practice Using a Realistic Evaluation Framework," International Journal of Medical Informatics, Vol. 78, No. 12, 2009, pp. 839-849. doi:10.1016/j.ijmedinf.2009.08.008

[115] H. Hyppönen, P. Doupi, P. Hämäläinen, J. Komulainen, P. Nykänen and R. Suomi, "Planning for National Health Information System Evaluation,” Studies in Health Technology and Informatics, Vol. 150, 2009, pp. 972-976.

[116] S. Sivic, L. Gojkovic and S. Huseinagic, "Evaluation of an Information System Model for Primary Health Care,” In: K.-P. Adlassnig, et al., Eds., Medical Informatics in a United and Healthy Europe, IOS Press, Amsterdam, 2009, pp. 106-110.

[117] I. C. Hou, H. C. Yu, Y. J. Hwang, J. Cheng, R. S. Wu, P. Chang. "The Evaluation of the Nurses' Work Performance after Nursing Information System Implementation in One Medical Center in Taiwan,” Studies in Health Technology and Informatics, Vol. 146, 2009, p. 708.

[118] F. Lau, "Extending the Infoway Benefits Evaluation Framework for Health Information Systems," Studies in Health Technology and Informatics, Vol. 143, 2009, pp. 406-413.

[119] Y. Y. Mei, J. Marquard, C. Jacelon and A. L. Defeo, "Designing and Evaluating an Electronic Patient Falls Reporting System: Perspectives for the Implementation of Health Information Technology in Long-Term Residential Care Facilities," International Journal of Medical Informatics, 2011. [Epub ahead of print] doi:10.1016/j.ijmedinf.2011.03.008

[120] E. Cummings and P. Turner, "Patient Self-Management and Chronic Illness: Evaluating Outcomes and Impacts of Information Technology," Studies in Health Technology and Informatics, Vol. 143, 2009, pp. 229-234.

[121] M. Magnus, J. Herwehe, L. Andrews, L. Gibson, N. Daigrepont, J. M. De Leon, N. E. Hyslop Jr., S. Styron, R. Wilcox, M. Kaiser and M. K. Butler, "Evaluating Health Information Technology: Provider Satisfaction with an HIV-Specific, Electronic Clinical Management and Reporting System,” AIDS Patient Care STDS, Vol. 23, No. 2, 2009, pp. 85-91. doi:10.1089/apc.2008.0053

[122] S. Hagens and A. Krose, "Evolution of a National Approach to Evaluating the Benefits of the Electronic Health Record," Studies in Health Technology and Informatics, Vol. 143, 2009, pp. 389-394.

[123] S. Petter and A. Fruhling, "Evaluating the Success of an Emergency Response Medical Information System,” International Journal of Medical Informatics, Vol. 80, No. 7, 2011, pp. 480-489. doi:10.1016/j.ijmedinf.2011.03.010

[124] I. Masic, D. Ciric, A. Pulja, I. Kulasin and H. Pandza, "Quality Assessment of Medical Education and Use of
Information Technology,” Studies in Health Technology and Informatics, Vol. 150, 2009, pp. 898-902.

[125] S. Khan, C. D. Maclean and B. Littenberg, "The Effect of the Vermont Diabetes Information System on Inpatient and Emergency Room Use: Results from a Randomized Trial," Health Outcomes Research in Medicine, Vol. 1, No. 1, 2010, pp. e61-e66. doi:10.1016/j.ehrm.2010.03.002

[126] M. Domingo, J. Lupón, B. González, E. Crespo, R. López, A. Ramos, A. Urrutia, G. Pera, J. M. Verdú and A. Bayes-Genis, "Evaluation of a Telemedicine System for Heart Failure Patients: Feasibility, Acceptance Rate, Satisfaction and Changes in Patient Behavior Results from the CARME (CAtalan Remote Management Evaluation) Study," European Journal of Cardiovascular Nursing, 2011. [Epub ahead of print] doi:10.1016/j.ejcnurse.2011.02.003

[127] K. Ando, J. Koyama, Y. Abe, T. Sato, M. Shoda, Y. Soga, M. Nobuyoshi, T. Honda, K. Nakao, K. Terata, K. Kadowaki, A. Maeda, S. Ogawa, T. Manaka, N. Hagiwara and K. Doi, "Feasibility Evaluation of a Remote Monitoring System for Implantable Cardiac Devices in Japan,” International Heart Journal, Vol. 52, No. 1, 2001, pp. 3943.

[128] P. Breen, K. Murphy, G. Browne, F. Molloy, V. Reid, C. Doherty, N. Delanty, S. Connolly and M. Fitzsimons, "Formative Evaluation of a Telemedicine Model for Delivering Clinical Neurophysiology Services Part II: The Referring Clinician and Patient Perspective," BMC Medical Informatics and Decision Making, Vol. 10, 2010, p. 49. doi:10.1186/1472-6947-10-49

[129] A. W. Armstrong, C. Sanders, A. D. Farbstein, G. Z. Wu, S. W. Lin, F. T. Liu and T. S. Nesbitt, "Evaluation and Comparison of Store-and-Forward Teledermatology Applications," Telemedicine and eHealth, Vol. 16, No. 4, 2010, pp. 424-438.

[130] M. E. Dávalos, M. T. French, A. E. Burdick, S. C. Simmons and F. Wang, "Economic Evaluation of Telemedicine: Review of the Literature and Research Guidelines for Benefit-Cost Analysis. The Role of Cost in Telemedicine Evaluation,” Telemedicine and eHealth, Vol. 15, No. 10, 2009, pp. 949-953.

[131] M. Le Goff-Pronost and C. Sicotte, “The Added Value of thorough Economic Evaluation of Telemedicine Networks," The European Journal of Health Economics, Vol. 11, No. 1, 2009, pp. 45-55. doi:10.1007/s10198-009-0162-5

[132] J. F. Lesesve and R. Garand, "Evaluation of a Telemedicine System for the Transmission of Morpho/Immunological Data Aiming at the Inclusion of Patients in a Therapeutic Trial,” International Journal of Telemedicine and Applications, 2009. [Epub ahead of print] doi:10.1155/2009/767145

[133] J. B. Smith, S. R. Lacey, A. R. Williams, S. L. Teasley, A. Olney, C. Hunt, K. S. Cox and C. Kemper, "Developing and Testing a Clinical Information System Evaluation Tool: Prioritizing Modifications through End-User Input,” Journal of Nursing Administration, Vol. 6, No. 6, 2011, pp. 252-258. doi:10.1097/NNA.0b013e31821c4634 
[134] C. Fröjd, C. L. Swenne, C. Rubertsson, L. Gunningberg and B. J. Wadensten, "Patient Information and Participation Still in Need of Improvement: Evaluation of Patients' Perceptions of Quality of Care," Journal of Nursing Management, Vol. 19, No. 2, 2011, pp. 226-236. doi:10.1111/j.1365-2834.2010.01197.x

[135] J. M. Palm, T. Dart, I. Dupuis, L. Leneveut and P. Degoulet, "Clinical Information System Post-Adoption Evaluation at the Georges Pompidou University Hospital," AMIA Annual Symposium Proceedings, Washington, 1317 November 2010, pp. 582-586.

[136] J. S. Wu, F. Y. Shih, C. H. Chiu, Y. L. Yeh, J. J. Yan, C. C. King and M. S. Ho, "Evaluation of an Adjustable Epidemiologic Information System,” PLoS One, Vol. 6, No. 1, 2011, p. e14596. doi:10.1371/journal.pone.0014596

[137] A. Krishnan, B. Nongkynrih, K. Yadav, S. Singh and V. Gupta, "Evaluation of Computerized Health Management Information System for Primary Health Care in Rural India,” BMC Health Services Research, Vol. 10, 2010, p. 310. doi:10.1186/1472-6963-10-310

[138] S. Hagens and A. Krose, "Evolution of a National Approach to Evaluating the Benefits of the Electronic Health Record," Studies in Health Technology and Informatics, Vol. 143, 2009, pp. 389-394.

[139] S. Petter and A. Fruhling, "Evaluating the Success of an Emergency Response Medical Information System," International Journal of Medical Informatics, Vol. 80, No.
7, 2011, pp. 480-489.

[140] I. Masic, D. Ciric, A. Pulja, I. Kulasin and H. Pandza, "Quality Assessment of Medical Education and Use of Information Technology," Studies in Health Technology and Informatics, Vol. 150, 2009, pp. 898-902.

[141] S. Khan, C. D. Maclean and B. Littenberg, "The Effect of the Vermont Diabetes Information System on Inpatient and Emergency Room Use: Results from a Randomized Trial," Health Outcomes Research in Medicine, Vol. 1, No. 1, 2010, pp. e61-e66. doi:10.1016/j.ehrm.2010.03.002

[142] E. Brynjolfsson and H. Lorin, "Computing Productivity: Firm Level Evidence,” MIT Sloan Working Paper No. 4210-01, 2003.

http://papers.ssrn.com/sol3/papers.cfm?abstract_id=2903 25

[143] V. Vimarlund, T. Timpka and N. Hallberg, "Healthcare Professional's Demand for Knowledge in Informatics," International Journal of Medical Informatics, Vol. 53, No. 2-3, 2003, 1999, pp. 107-114.

[144] V. Vimarlund, et al., "Identifying Utility of Investments in Large Infrastructures for Health and Social Care,” Research Report, 2009. (only in Swedish)

[145] V. Vimarlund, et al., "Capturing Outcomes from Investments in ICT in Health and Social Care. An Analysis Model to Evaluation and Control,” Research Report, 2011. (Only in Swedish) 